\title{
Protease prospecion and determination of its isoenzymes activity in cocoa cultivars (Theobroma cacao $\mathrm{L}$.)
}

\author{
Paulo Túlio de Souza SILVEIRA ${ }^{1 \star}$, Lorena de Jesus Próculo MELO ${ }^{1}$, Luciane Santos SOUZA ${ }^{1}$, \\ Eliete da Silva BISPO ${ }^{1}$, Sérgio Eduardo SOARES ${ }^{1}$
}

\begin{abstract}
Our objective was to characterize the protease enzymatic activity and its isoenzymes on cacao cultivars PH 16 and TSH 1188, produced in southern Bahia, linking it to the conditions of the fermentation process. Proteases were extracted and semi-purified, their activities determined changing substrate, $\mathrm{pH}$ and temperature, and the values compared with the parameters of fermentation ( $\mathrm{pH}$ and temperature), and yet determined the kinetic parameters and the activity of its isoenzymes: aminopeptidase, carboxypeptidase and endoprotease. In the experimental conditions, differences in protease activities were shown as to different cocoa cultivars on various conditions. The albumin stands out as the preferred enzyme substrate, in a $\mathrm{pH}$ range between and 6 and temperatures between $29^{\circ} \mathrm{C}$ and $50^{\circ} \mathrm{C}$. As for the isoenzymes activity, an increased activity in these seeds and in the cultivar TSH 1188 was observed. When correlated with the fermentative parameters, the conditions for enzymatic activity are not the best determined, with emphasis on farming $\mathrm{pH} 16$ presenting its fermentation conditions far from those found as optimal, especially in $\mathrm{pH}$ evaluation, since temperature varies very little between the two cultivars.
\end{abstract}

Keywords: aminopeptidase; carboxypeptidase; endoprotease; peptide bonds; amino acids.

Practical Application: The work characterizes proteases and determines its isoenzymes activity, highlighting and discussing its importance in the formation of precursors of the chocolate flavor. The knowledge on the enzyme characteristics opens possibilities for future technological interventions in the cocoa fermentation process, to improve the quality of the raw material and, consequently, of monovarietal chocolate.

\section{Introduction}

The cocoa cultivation occurs for various purposes such as the preparation of pastes and extraction of fat (cocoa butter), exploration of compounds such as flavonoids and purine alkaloids extensively studied in the pharmaceutical industry, but mainly for the production of chocolate, one of the most appreciated and consumed foods in the world (Amores \& Jiménez, 2007; Amores et al., 2009; Araujo et al., 2013). Out of the 22 known families of the genus Theobroma, only cocoa (Theobroma cacao L.) and cupuaçu (Theobroma grandiflorum L.) are used for economic purposes (Sodré, 2007).

For chocolatee production, the first step is to submit the cocoa pulp and seeds to the fermentation process, in which several biochemical reactions happen, in addition to the separation of pulp and seed. This step is responsible for the development of the precursors and the flavor compounds in cocoa beans (Oetterer, 2006).

During the fermentation process, the envelope pulp is degraded by the action of acetic-acid bacteria, lactic acid and yeasts naturally present in the environment, thereby increasing the temperature of fermentation to about $50^{\circ} \mathrm{C}$. The acid formation may decrease the $\mathrm{pH}$, which together with the increase of temperature, is responsible for the death of the embryo and the acidification of the stored fabric, enabling the loss of selective permeability membranes and consequently the counted enzymes with substrates. These endogenous enzymes are responsible for the flavor precursors in chocolate (Cruz et al., 2013).

Since the second half of the twentieth century, the enzyme activity in the fermentation of cocoa beans has been studied, and key enzymes for the formation of the chocolate flavor are seen to be the polyphenol oxidase, invertase and protease (Hansen et al., 1998).

Proteases are enzymes which act on proteins turning them into peptides of lower molecular weight or amino acids (Lima et al., 2001). It is already known that proteases, during proteolysis, produce precursors (peptides and free amino acids) which will, along with reducing sugars, participate in the Maillard reaction during roasting, thereby contributing to the development of the flavor and the taste of chocolate (Voigt et al., 1994; Huang \& Barringer, 2010). 
As for the mode of action, proteases are divided into exopeptidases, which operate in the polypeptide chain termination and endopeptidases, which act on the links inside the protein chain. Among exopeptidases, there are those which catalyze the cleavage of its substrates from a carboxy- or amino-terminal portion, carboxypeptidases and aminopeptidases, respectively (Barrett et al., 2004; Turk, 2006).

Despite the knowledge on the importance of enzymes participating in the cocoa almonds fermentation process, there is still need of systematic studies addressing the comparison between the different cocoa cultivars (Hansen et al., 1998). The identification and characterization of the cocoa enzymes are sensitive and laborious, especially for several variations which occur during all cocoa processing steps for the production of chocolate (Sturm, 1999).

Therefore, our aim was to characterize the enzymatic activity of proteases and determine the activity of its isoenzymes in two cacao cultivars, PH 16 and TSH 1188, produced in southern Bahia, relating them to the conditions of the fermentation process, and therefore contributing for future technological intercessions in order to improve the quality of the raw material in the production of chocolates.

\section{Materials and methods}

\subsection{Materials}

The PH16 cacao cultivars (hybrid Forastero) and the TSH 1188 (Hybrid Trinitarian) were produced at Fazenda Lajedo

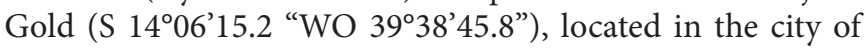
Ibirataia in the south of the state of Bahia, Brazil. The material was given by producers, according to the availability in the trial implementation period.

\subsection{Methods}

\section{Fermentation}

The fermentation was carried out on the farm in wooden troughs: PH 16 farming in $70 \times 70 \times 65 \mathrm{~cm}$ troughs for seven days, and TSH 1188 in $40 \times 40 \times 35 \mathrm{~cm}$ troughs for six days, both with holes ( $1.27 \mathrm{~cm}$ each) at the bottom and sides to allow the liquid produced during fermentation to flow. The difference in size of the troughs was due to material availability during the collection period.

\section{Sample collection}

Samples were collected at the beginning of fermentation, time zero, and every 6 hours until the end of the process. Throughout fermentation, temperature (Digital Thermometer MINIPA, MT model - 450, Brazil) and $\mathrm{pH}$ ( $\mathrm{pH}$ digital meter Digimed DM-23, Brazil) of the mass (Association of Official Analytical Chemists, 2000) were measured.

\section{Extraction of the pulp and seed proteases}

The extraction was performed according to the methodology described by Gomez et al. (1999) using 100g of cocoa beans. The pulps were separated from the seeds manually and immersed in
$0.1 \mathrm{M}$ Tris- $\mathrm{HCl} \mathrm{pH} 7.5$ buffer at a ratio of $1: 2(\mathrm{w} / \mathrm{v})$ for 3 minutes comminuted and homogenized for 30 minutes at $4{ }^{\circ} \mathrm{C}$ to separate the pulp adhered seeds. The homogenate was centrifuged in a HITACHI refrigerated centrifuge (model CR22GIII, Japan) at $20,000 \times \mathrm{g}$ for $10 \mathrm{~min}$ at $4{ }^{\circ} \mathrm{C}$. The supernatant (extract) was stored at $-18^{\circ} \mathrm{C}$ to perform partial purification. Seeds removed from the extraction of the pulps were freeze-dried (Lyophilizer Liotop, L108 model, Brazil) and subsequently degreased, using petroleum ether as solvent (Yusep et al., 2002) and treated with acetone for polyphenols removal as described by Hansen et al. (1998). After evaporation of the solvent, the powder treated seeds were suspended in $0.2 \mathrm{M}$ sodium phosphate buffer, $\mathrm{pH} 7.5$ at $4{ }^{\circ} \mathrm{C}$ in the ratio $1: 5(\mathrm{w} / \mathrm{v})$ and homogenized in magnetic stirrer for 30 minutes at $4{ }^{\circ} \mathrm{C}$. After mixing, the suspension was centrifuged at $20,000 \times \mathrm{g}$ for $10 \mathrm{~min}$ at $4{ }^{\circ} \mathrm{C}$, the supernatant stored at $-18{ }^{\circ} \mathrm{C}$ for subsequent steps (Misnawi et al., 2002).

Partial purification of the pulp and seed proteases

Purification was performed according to Deuner et al. (2005), to which ammonium sulfate extracts [NH4) 2SO4] were added, in sufficient quantity to provide $80 \%$ saturation. Salt was added slowly with gentle stirring at $4{ }^{\circ} \mathrm{C}$ and the mixture centrifuged at $20,000 \mathrm{xg}$ for 60 minutes at $4^{\circ} \mathrm{C}$, separating the precipitate. Pulp extracts were dialyzed for 24 hours at $4{ }^{\circ} \mathrm{C}$ with Tris- $\mathrm{HCl} 0.01 \mathrm{M}$ buffer Solution at $\mathrm{pH} 7.5$ cellulose membrane $(43 \mathrm{~mm})$ to obtain the partially purified extract (Silva et al., 2003) which was stored at $-18^{\circ} \mathrm{C}$ for analyzes. As for the seed extracts, they were dialyzed for 48 hours at $4{ }^{\circ} \mathrm{C}$ in sodium phosphate buffer $0.2 \mathrm{M} \mathrm{pH} 7.5$ in celulole membrane (43MM) to obtain partially purified extract (Silva et al., 2003), which was stored at $-18{ }^{\circ} \mathrm{C}$ for analyzes.

\section{Determination of the activity of proteases}

The protease activity in pulp and seed was determined by taking aliquots of $100 \mathrm{l}$ of the purified extract and mixing them to 100 of Tris- $\mathrm{HCl} 0.01 \mathrm{M}$ buffer $\mathrm{pH}$ 9. To this mixture, $100 \mathrm{l}$ of substrate (azocasein, bovine serum albumin, and gelatin) with different concentrations $(0.5,1,2,3$ and $4 \mathrm{mg} / \mathrm{mL})$ was added and incubated at $37^{\circ} \mathrm{C}$ for 30 minutes. The reaction was stopped by the addition of $500 \mathrm{uL}$ of trichloroacetic acid (TCA) at $10 \%$. After centrifugation at $10,000 \times \mathrm{g}$ for 5 minutes, $200 \mathrm{uL}$ of $1.8 \mathrm{~N} \mathrm{NaOH}$ was added to the supernatant. The reading of the sample was carried out with an spectrophotometer (Biochrom, Model Libra S50, Germany) at a wavelength of $420 \mathrm{~nm}$ for azocasein and $280 \mathrm{~nm}$ for other substrates. For quantification, an Enzyme Unit (EU) was considered, the necessary amount of enzyme required to increase the absorbance of 0.01 . A control was used with the addition of TCA prior to sample incubation (Giongo, 2006).

Effect of $\mathrm{pH}$ and temperature on the activity of the proteases

To determine the optimal $\mathrm{pH}$ of pulp and seed on both cocoa varieties, the substrate with higher activity was used, and replacement of buffers used by $0.1 \mathrm{M}$ sodium citrate $(\mathrm{pH} 2,3,4,5)$ and phosphate $0.1 \mathrm{M}$ sodium ( $\mathrm{pH} 6.7$ and 8). 
To determine the optimal temperature, the substrate and the $\mathrm{pH}$ with higher activity were used, and incubation temperatures were $20,30,40,50$ and $60^{\circ} \mathrm{C}$ (Giongo, 2006).

\section{Aminopeptidase activity determination}

The aminopeptidase was extracted by incubating $30 \mathrm{mg}$ of the powder treated seed and pulp (lyophilized) with $60 \mathrm{mg}$ of polyvinylpolypyrrolidone, $1.8 \mathrm{~mL}$ of $0.1 \mathrm{M}$ phosphate buffer $\mathrm{pH} \quad 7.0$ and $1 \%$ Triton $\mathrm{X}-100$ for 30 minutes at $4{ }^{\circ} \mathrm{C}$. After obtaining the extract, they were again incubated with a mixture of 890 uL 0.1 M phosphate buffer, $\mathrm{pH} 7.0,1 \%$ Triton X-100, $100 \mathrm{uL}$ of extract and $10 \mathrm{uL}$ of $200 \mathrm{mM}$ leucine polyvynilpolypyrrolidona -p-nitroaniline solution. The substrate was composed of 200 of mM leucine-p-nitroaniline (H-Leu-pNA), which was prepared by dissolving in dimethylsulfoxide (DMS). The reaction was performed for 30 minutes at $37^{\circ} \mathrm{C}$ and the absorbance measured at $405 \mathrm{~nm}$. The enzyme activity was measured in the supernatant after two centrifugations for 10 minutes at 10,000 to $20,000 \times \mathrm{g}$. The enzyme activity was calculated from a standard curve of leucine-p-nitroaniline (Hansen et al., 1998).

\section{Determination of the carboxypeptidase activity}

A solution of $1 \mathrm{~mL}$ of extract was incubated with a solution of Pepstatin A (10ug / mL) for 1 hour in an ice bath for inhibiting endoprotease (Amin et al., 1998; Voigt et al., 1994). To an aliquot $(0.5 \mathrm{ml})$ of this mixture, $0.5 \mathrm{~mL}$ of $0.2 \mathrm{M}$ sodium phosphate buffer, $\mathrm{pH} 5.8$ was added, containing $5 \mathrm{mM}$ leucine-p-nitroaniline as substrate, which was prepared from a stock solution $125 \mathrm{mM}$ in methanol. The mixture was then incubated at $45^{\circ} \mathrm{C}$ for 30 minutes. The reaction was stopped adding $0.5 \mathrm{ml}$ of $20 \%$ trichloroacetic acid solution, the tubes were maintained for 15 minutes at a room temperature and centrifuged at $10,000 \times \mathrm{g}$ for 10 minutes. The ninhydrin reaction was performed as described for the endoprotease activity and was also calculated from a leucin estandard curve. One carboxypeptidase unit was the amount of enzyme required to release one $\mathrm{mmol}$ of leucine per minute at pH 5.8 and $45^{\circ} \mathrm{C}$ (Misnawi et al., 2002; Hansen et al., 1998).

\section{Determination of endoprotease activity}

To determine endoprotease activity, aliquots of $500 \mathrm{uL}$ of the purified extract were incubated at $45^{\circ} \mathrm{C}$ for 30 minutes with a mixture containing $20 \mathrm{mg}$ of bovine albumin and $2.0 \mathrm{~mL}$ of $0.2 \mathrm{M}$ phosphate buffer, $\mathrm{pH}$ 3.5. The reaction was stopped adding $0.5 \mathrm{~mL}$ of trichloroacetic acid at $20 \%$ and then centrifuged at 10,000 $\times \mathrm{g}$ for 15 minutes (Amin et al., 1998; Hansen et al., 1998). The amount of proteolysis products was determined by the ninhydrin reaction, which was performed by mixing $400 \mathrm{uL}$ of the supernatant with $400 \mathrm{uL}$ of the ninhydrin reagent. The mixtures were incubated for 15 minutes in a boiling water bath and ice-cooled, ethanol was finally added $(50 \%, 1 \mathrm{~mL})$, quickly mixed, and the absorbance was measured at $570 \mathrm{~nm}$. Anendoprotease unit was considered as the amount of enzyme required for releasing $1 \mathrm{mMol}$ of amino groups per minute. L-Leucine was used as the standard (Misnawi et al., 2002; Hansen et al., 1998).

\subsection{Correlation between the fermentation parameters and the enzymatic activity of the extracts}

The results of the enzymatic activity of proteases in extracts of the pulp and seed of cultivars in Zero Time, were compared with the fermentation parameters ( $\mathrm{pH}$ and temperature), to design and evaluate the behavior of the enzyme throughout the process.

\subsection{Determination of protein content in the extracts}

To calculate the specific enzymatic activity, the protein content was determined by the method of Lowry et al. (1951).

\subsection{Statistical analysis}

All analyzes were performed with two replications in quintuplicatas and averages with their respective standard deviations of the data were determined.

For the isoenzymes activities, a completely randomized design (CRD) was used, submitting the data to variance analysis and comparing the means with Tukey's test at $1 \%$ probability, through ASSISTAT Version 7.7 beta program - 2012 (Silva \& Azevedo, 2006).

\section{Results and discussion}

\subsection{Proteases activity determination}

Among the substrates tested for azocasein, no enzymatic activity in both cacao cultivars was found. In Figure 1 the specific enzymatic activity of proteases in cocoa cultivars $\mathrm{pH} 16$ and TSH 1188 was expressed to the substrates bovine serum albumin and gelatin. As for the bovine serum albumin substrate (Figure 1), the maximum activity of the pulp cultivar $\mathrm{pH} 16$ was 2.0 UE.mg protein- 1 and for the TSH 1188 was 0.7 UE.mg protein-1, and the maximum values for both cultivars achieved with $1.5 \mathrm{mg} / \mathrm{mL}$ bovine serum albumin as substrate. In the seed maximum activity of $\mathrm{pH} 16$ was 1.4 UE.mg-1 protein with $1.4 \mathrm{mg} / \mathrm{mL}$ substrate, and the TSH 1188 was 0.4 UE.mg protein-1, $3 \mathrm{mg} / \mathrm{mL}$ substrate (Figure 1B).

For the substrate gelatin, the variety $\mathrm{PH} 16$ Pulp activity reached 1.2 protein-1 UE.mg with $3.1 \mathrm{mg} / \mathrm{ml}$ substrate, whereas for the TSH 1188 the activity was not more than 0.5 UE.mg protein-1, $4 \mathrm{mg} / \mathrm{mL}$ gelatin (Figure 1C). In the seed, maximum activity of $\mathrm{pH} 16$ was 0.8 UE.mg-1 protein, $1 \mathrm{mg} / \mathrm{mL}$ substrate, whereas in the variety TSH 1188 the maximum enzymatic activity was 0.3 UE.mg protein-1, and this maximum value achieved with $1.6 \mathrm{mg} / \mathrm{ml}$ gelatin (Figure 1D).

Other authors such as Biehl et al. (1982), Amin et al. (1997) and Hansen et al. (2000) in their studies, they have observed that there is a difference in the proteases activity in different cocoa genotypes. Similar results were found by Voigt et al. (1994).

Based on the above values, to determine the $\mathrm{pH}$ and the enzyme optimal temperature, bovine serum albumin was used as the preferred substrate at a concentration of $1.5 \mathrm{mg} / \mathrm{mL}$ for further analysis. 
A.

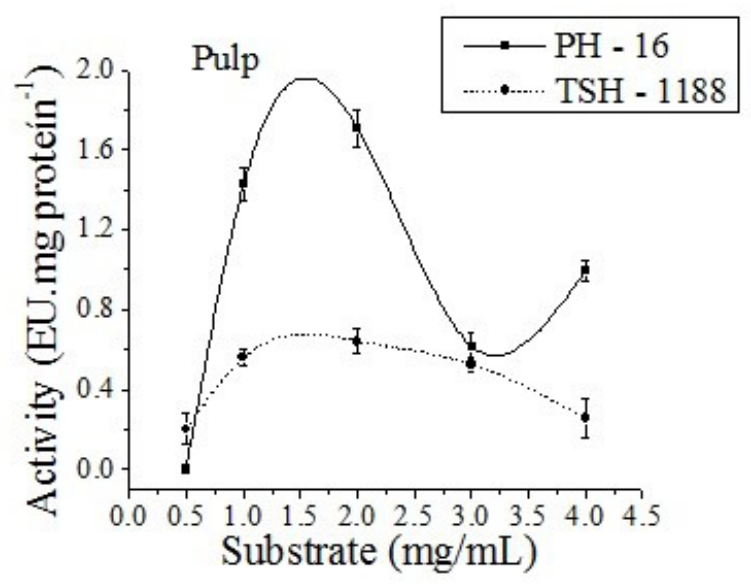

B.

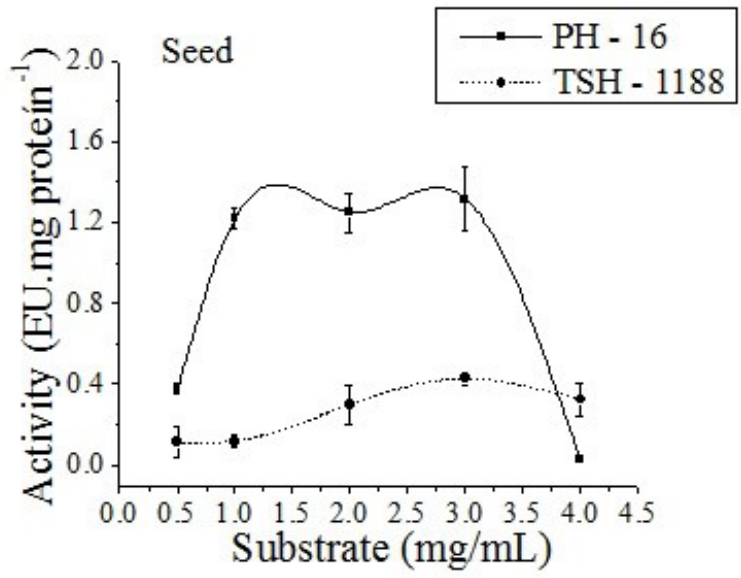

C.

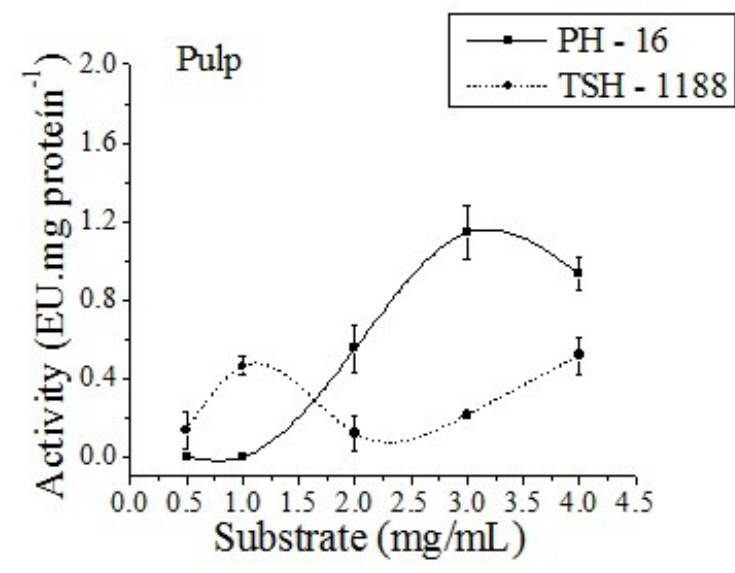

D.

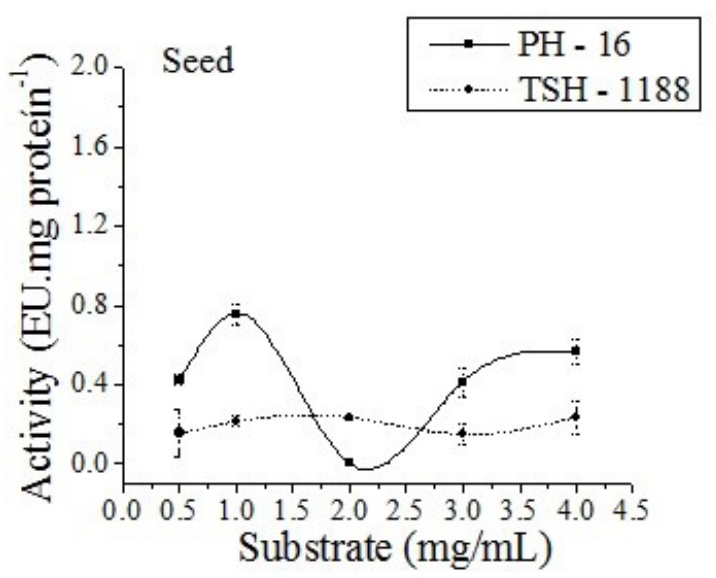

Figure 1. Specific proteases activity in cocoa cultivars PH 16 and TSH 1188 on different substrates and concentrations. (A) Albumin Pulp; (B) Albumin Seed; (C) Gelatine Pulp; (D) Gelatine Seed.

\subsection{Effect of pH on the protease activity}

Figure 2 shows the results of protease activity as $\mathrm{pH}$ changes from 2 to 8 . The results present a higher activity for the $\mathrm{pH} 16$ cultivar, which reached 1.6 UE.mg of protein-1 at pH 5.7 in the pulp and 1.5 UE.mg of protein-1, pH 3.1 in the seed. Yet the TSH 1188 cultivar had a higher activity at $\mathrm{pH} 4.1$, and 0.8 in the pulp UE.mg protein-1, and kernel UE.mg 0.3-1 protein.

The results highlight an optimal range of protease activity between $\mathrm{pH} 3$ and 6 , in all genotypes and as for the variables pulp and seed, results show what has been already been observed in preferred substrate determination, where the highest activity observed was in the pulp and in the cultivar pH 16. Studies corroborate with the influence of $\mathrm{pH}$ on the proteases activity such as those conducted by Hansen et al. (1998), Voigt et al. (1994).

From the obtained results, to determine the optimal temperature of protease, $\mathrm{pH} 5.7$ and 3.1 for pulp and seed $\mathrm{PH} 16$ was used, respectively, and pH 4.1 for pulp and seed TSH 1188.

\subsection{Effect of temperature on the activity of Proteases}

The effect of different temperatures $\left(20\right.$ to $\left.60^{\circ} \mathrm{C}\right)$ on protease activity was expressed in Figure 3. The cultivar $\mathrm{pH} 16$ reached a maximum activity (2.0 UE.mg of protein-1) for the pulp at $50{ }^{\circ} \mathrm{C}$, whereas the seed presented reduced activity (1.5 UE.mg of protein-1) at this temperature, reaching its peak at $32{ }^{\circ} \mathrm{C}$. The cultivar TSH 1188 showed maximum activity (0.8 UE.mg of protein-1) in the pulp also at $50^{\circ} \mathrm{C}$, since the seed had maximal activity of 0.5 UE.mg of protein- 1 at $29^{\circ} \mathrm{C}$.

Thus, pulp proteases showed an optimal activity at $50^{\circ} \mathrm{C}$, and those in the seed, in a range of $29-32{ }^{\circ} \mathrm{C}$ in both varieties, showed a higher activity in the pulps, and, among the varieties, in the $\mathrm{PH} 16$.

Studies also show variations in the proteases activity with temperature changes, such as the studies conducted by Marco and Felix (2002) who analyzed proteases isolated from the Brazilian cocoa fungi. Larcher et al. (1992) and Wang et al. (2005) also 
A.

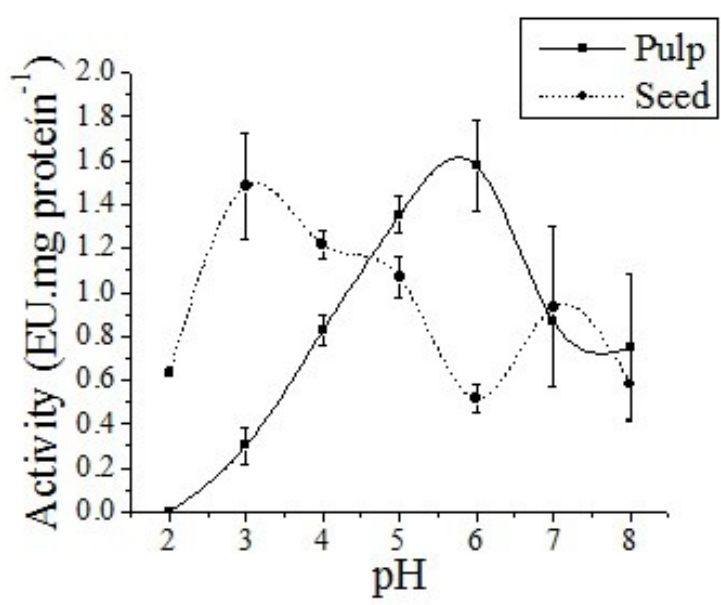

B.

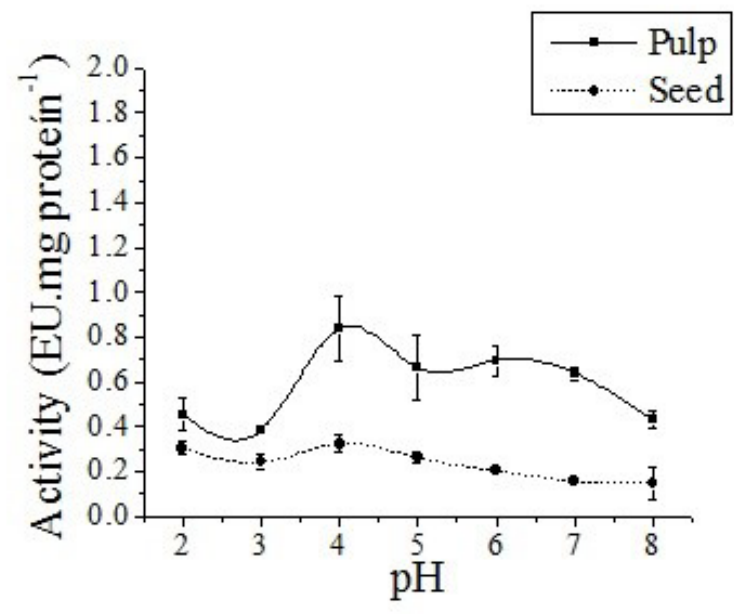

Figure 2. Effect of pH on the Protease Activity. (A) PH 16; (B) TSH 1188.

A.

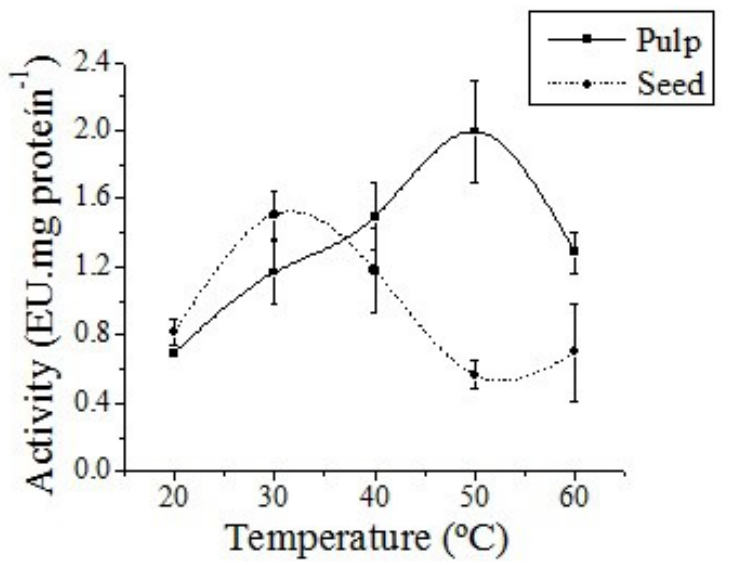

B.

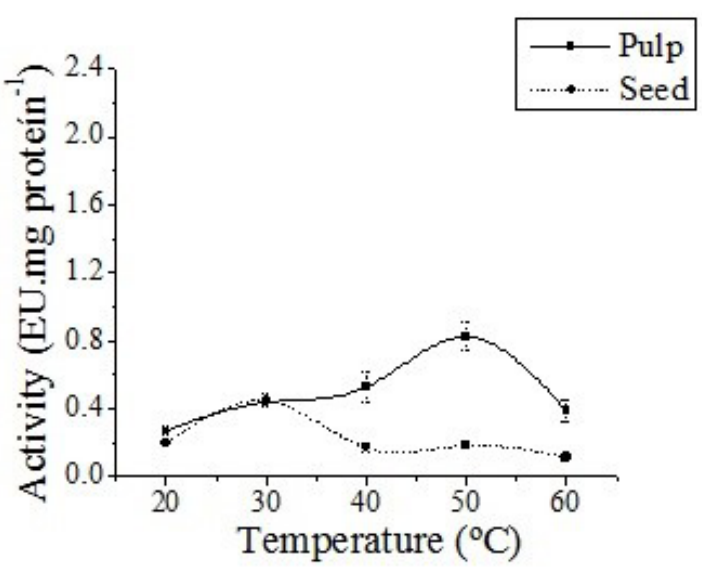

Figure 3. Effect of temperature on the activity of proteases. (A) PH 16; (B) TSH 1188.

reported the production of protease from Aspergillus fumigatus isolates cocoa with optimal activity at temperatures of $42{ }^{\circ} \mathrm{C}$ and $40{ }^{\circ} \mathrm{C}$ respectively.

\subsection{Determination of the activity of the isoenzymes (aminopeptidase, carboxypeptidase and endoprotease)}

The activity of the three isozymes of the protease, aminopeptidase, carboxipeptidase and endoprotease, are expressed in Figure 4. In this figure, a difference in their activities was observed, with the endoprotease with higher activity, even higher than the sum of the other two isozymes, indicating a greater presence of this isoenzyme in the analyzed cocoa varieties. However, it is important to note that, according to Barrett (1980), there are proteases that have both exopeptidic and endopeptídic activity.

The aminopeptidase, shown in Figure 4A, presented an activity of 0.62 units g- 1 Dry Weight defatted - PSD and $0.64 \mathrm{~g} 1$ PSD-units to pulp $16 \mathrm{pH}$ cultivars and TSH 1188, respectively, with no significant differences from the Tukey's test at $1 \%$ probability. Yet the seeds presented for the $\mathrm{PH} 16$ cultivars and the TSH 1188 an activity of 0.68 g-1 PSD units, again with no significant differences. When compared with pulp and seeds, a lower activity for pulp can be observed, with significant differences for the same statistical test applied.

The carboxipeptidase activity is shown in Figure 4B, and presented for cultivar PH 16 an activity of 0.56 g-1 PSD units and 0.72 units g-1 PSD, and for the cultivar TSH 1188 an activity of $0.59 \mathrm{~g}-0.7 \mathrm{~g} 1 \mathrm{PSD}$ units and 1 PSD-units, for pulps and seeds respectively. According to Tukey, at $1 \%$ probability there is no significant difference between pulp activities of the two cultivars and seeds among the cultivars. But when comparing the pulp activity with the seeds there is a significant difference with a higher activity detected in the seed.

Values close to those were found by Hansen et al. (1998) and Hansen et al. (2000) for the aminopeptidase activity. 
A.

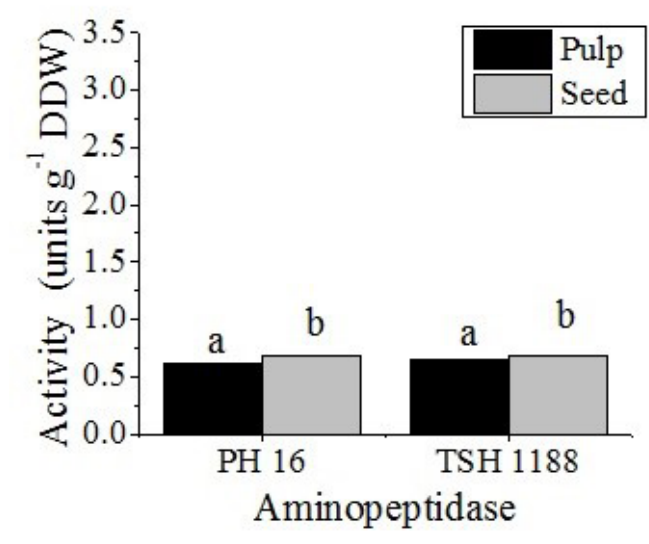

B.

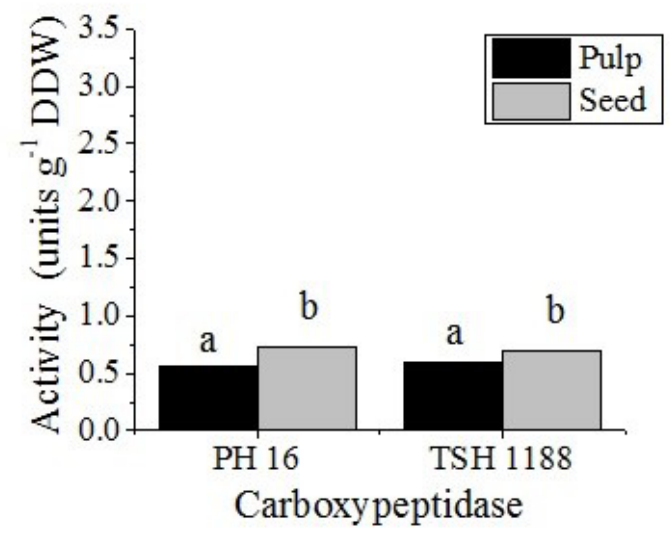

C.

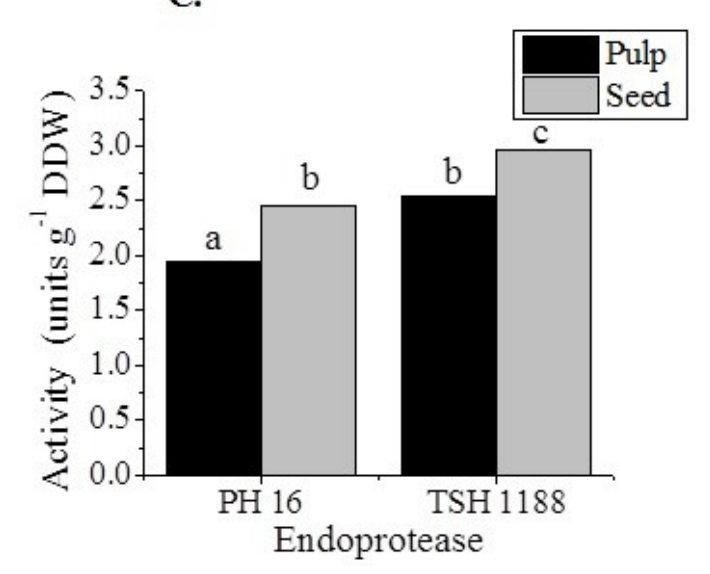

Figure 4. Activity of the three isozymes of the protease on both cocoa varieties. (A) Aminopeptidase; (B) Carboxypeptidase; (C) Endoprotease. Different letters are significantly different from those in Tukey's test $(\mathrm{p}<0.001)$.

Endoprotease (Figure 4C) has the highest activity among the tested isoenzymes, being $1.94 \mathrm{~g}$-1 PSD units for pulp and 2.46 g-1 PSD units for seed for the cultivar PH 16. As for the farming TSH 1188, for the pulp an activity of $2.54 \mathrm{~g} 1 \mathrm{PSD}$-units and 2.96 units seed-1 PSD g was obtained. Tukey's test at $1 \%$ probability, pulp and seed activities presented significant differences, and in both cases a higher activity for the TSH 1188 cultivar, the only samples which did not differ statistically was the seed of the PH 16 and the pulp 1188. This higher activity on TSH 1188 shows a greater presence of endoprotease in the cultivar compared to the $\mathrm{PH} 16$. However, as in the other isoenzymes, a higher activity is observed, and therefore, a greater presence in the seed than in the pulp. The results corroborate with those found by Hansen et al. (2000) and Misnawi et al. (2002). Hansen et al. (2000) found that there are significant differences in the isoenzymes activities in various cacao cultivars.

\subsection{Correlation between the fermentation parameters and the protease activity of the extracts}

After determining the necessary parameters for optimal enzyme activity, $\mathrm{pH}$ and temperature, a correlation between the ones obtained in this study and those measured in the cocoa mass in the fermentation troughs was made, with the objective of elucidating the protease activity period as well as urging the need for intervention in certain phases of the fermentation process.

In the $\mathrm{pH} 16$ cultivar (Figure 5), the $\mathrm{pH}$ of the pulp close to 4 in the cocoa mass can be observed, although the $\mathrm{pH}$ of optimal enzyme activity is 5.7 (Figure 2), likewise the seed (Figure 5B), which in the trough undergoes a $\mathrm{pH}$ variation between 4 and 7 , but has its optimal activity in pH 3.1 (Figure 2).

When assessing temperature (Figure $5 \mathrm{C}$ ) proteases activities in the seeds happen mainly at the initial phase of fermentation, since its optimal temperature is $31^{\circ} \mathrm{C}$ (Figure 3 ), and values close to those are only observed in the first 48 hours. As for the pulp proteases, they have as optimal temperature $50{ }^{\circ} \mathrm{C}$ (Figure 3B), and temperatures close to that are only reached after $84 \mathrm{hs}$ of fermentation, but lasts throughout the rest of the process, which implies a longer period of action of seed proteases than the pulp in the fermentation process.

A different behavior from what occurs in the PH 16 cultivar can be seen in the cultivar TSH 1188 when we correlate the enzyme optimal performance with its fermentation parameters (Figure 6). 
A.

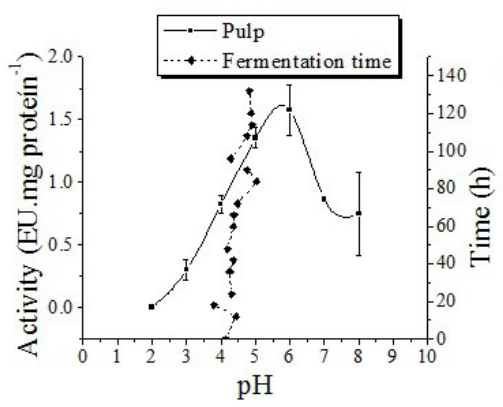

c.

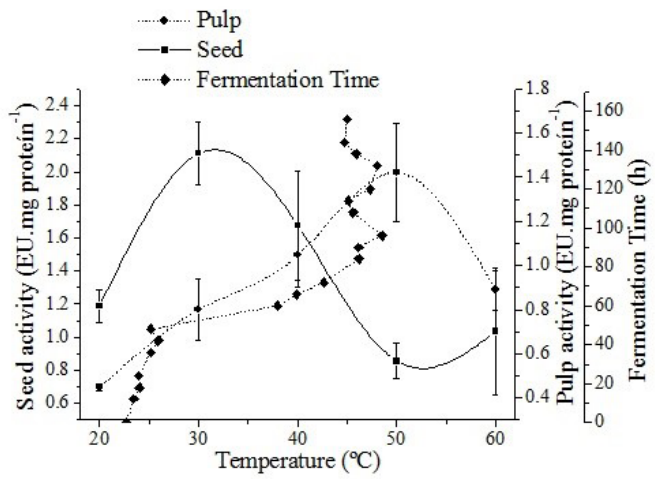

Figure 5. Correlation between the $\mathrm{pH}$ of pulp and seed and fermentation temperature, $\mathrm{pH}$ and optimal temperature of the protease activity for cultivar PH 16. (A) pH Pulp; (B) pH Seed; (C) Temperature.

A.

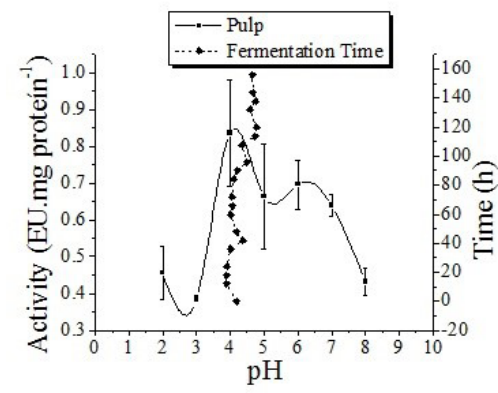

c.
B.

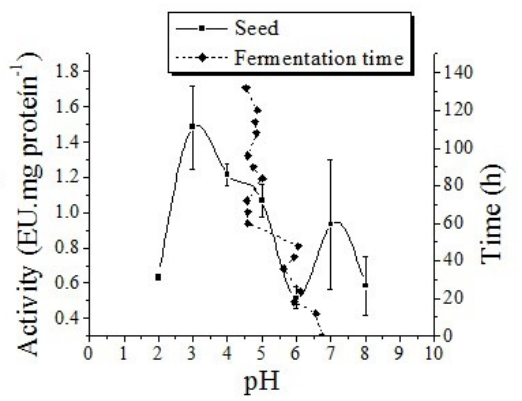


In cultivar TSH 1188, a pH next to the fermentation trough 4 can be observed (Figure 6) for the pulp, and the optimal enzyme activity also occurs near $\mathrm{pH} 4$, being 4.1 found in this study (Figure 2B). In seed, excellent performance also occurs at 4.1 (Figure $2 \mathrm{~B}$ ), but in the trough the $\mathrm{pH}$ ranges from 4 to 7 being close to 4 , beginning 84 after hours of fermentation (Figure 6B), which implies a major action of this enzyme in the seed at the end of fermentation, and its performance in the pulp during all the fermentation process.

In the assessment of temperature (Figure 6C), as well as for the $\mathrm{pH} 16$ cultivar, proteases activities in seeds happen mainly at the initial phase of fermentation, since their optimal temperature is $29^{\circ} \mathrm{C}$, and values near those are only observed in the first 42 hours. Since pulp proteases have $50^{\circ} \mathrm{C}$ as optimal temperature, and temperatures close to these are only reached after 60 hours of fermentation, but last throughout the remaining process, which involves a longer period of action of seed proteases in the beginning and of the pulp, at the end of the fermentation process.

Nascimento \& Martins (2006) state that proteases remain active in a wide range of $\mathrm{pH}$ and temperature, but they also note that, these variations influence the enzyme activity as shown by this study.

\section{Conclusions}

Protease activities in both cultivars showed the highest values for serum bovine albumin. The $\mathrm{pH}$ influences the enzyme activity, with variations among different cultivars. In general, the activity was satisfactory in a range between $\mathrm{pH} 3$ and 6 . The temperature has influence on the enzyme activity, presenting the same values of optimal temperatures for pulps, but different for seeds. In general, a higher activity was evidenced for pulps rather than for seed, and for cultivar PH 16 rather than for cultivar TSH 1188. The isozymes activity of aminopeptidase, carboxypeptidase and endoprotease was mostly found in seeds, with a greater emphasis on cultivar TSH 1188. The enzyme activity is not exploited at its fullest, for the factors analyzed ( $\mathrm{pH}$ and temperature) are far from being optimal so as to maximize its catalytic activities. Cultivar $\mathrm{PH} 16$ presents its fermentation conditions more distant from those found as optimal for enzymatic activity as assessed in this study, particularly in the $\mathrm{pH}$ evaluation, since the temperature varies slightly between the two cultivars.

\section{Acknowledgements}

The authors thank the National Council for Scientific and Technological Development (CNPq), the Higher Education Personnel Improvement Coordination (CAPES) and the Foundation of the State of Bahia Research (FAPESB) for financial support and Fazenda Lajedo do Ouro for the availability of samples.

\section{References}

Amin, I., Jinap, S., \& Jamilah, B. (1997). Vicilin-class globulin and their degradation during cocoa fermentation. Food Chemistry, 59(1), 1-5. http://dx.doi.org/10.1016/0308-8146(95)00188-3.

Amin, I., Jinap, S., \& Jamilah, B. (1998). Proteolytic activity (aspartic endoproteinase and carboxypeptidase) of cocoa bean during fermentation.
Journal of the Science of Food and Agriculture, 76(1), 123-128. http:// dx.doi.org/10.1002/(SICI)1097-0010(199801)76:1<123::AIDJSFA917>3.0.CO;2-N.

Amores, F., \& Jiménez, J. (2007). Aspectos de lacalidad de cacao (pp. 1-90). Quevedo: INIAP.

Amores, F., Palacios, A., Jiménez, J., \& Zhang, D. (2009). Entorno ambiental, genética, atributos de calidad y singularización Del cação em elnor oriente de laprovincia de esmeraldas (120p., Boletín Técnico, 135), Quevedo: INIAP.

Araujo, Q. R., Gattward, J. N., Almoosawi, S., Silva, M. D. C., Dantas, P. A., \& Araujo, Q. R. Jr. (2013). Cacao and human health: from head to foot: a review. Critical Reviews in Food Science and Nutrition, 56(1), 1-12. PMid:24915376. http://dx.doi.org/10.1080/10408398 .2012 .657921 .

Association of Official Analytical Chemists - AOAC. (2000). Official methods of analysis of the Association of Official Analytical Chemists. Arlington: AOAC.

Barrett, A. J., Rawlings, N. D., \& Woessner, J. F. (2004). Handbook of proteolytic enzymes. London: Elsevier.

Barrett, A. J. (1980). The many forms and functions of cellular proteinases. Federation Proceedings, 39(1), 9-14. PMid:6985872.

Biehl, B., Wewetzer, C., \& Passern, D. (1982). Vacuolar (storage) protein of cocoa seeds and their degradation during germination and fermentation. Journal of Science of Food and Agriculture, 33(12), 1291-1304. http://dx.doi.org/10.1002/jsfa.2740331216.

Cruz, J. F. M., Leite, P. B., Soares, S. E., \& Bispo, E. S. (2013). Assessment of the fermentative process from different cocoa cultivars produced in Southern Bahia, Brazil. African Journal of Biotechnology, 12(33), 5218-5225. http://dx.doi.org/10.5897/AJB2013.12122.

Deuner, S., Ferreita, L. S., Bacarin, M. A., Bervald, C. M. P., \& Zanatta, E. R. (2005). Caracterização parcial da invertase ácida solúvel em tubérculos de batata: energia de ativação e efeito de inibidores. Revista Brasileira de Agrociência, 11(1), 45-50.

Giongo, J. L. (2006). Caracterização e aplicação de proteases produzidas por linhagens de Bacillussp (Dissertação de Mestrado). Faculdade de Agronomia, Universidade Federal do Rio Grande do Sul, Porto Alegre.

Gomez, M. L. P. A., Lajolo, F. M., \& Cordenunsi, B. R. (1999). Metabolismo de carboidratos durante o amadurecimento do mamão (Caricapapaya, L. cv. Solo): influência da radiação gama. Ciência e Tecnologia de Alimentos., 19(2), 246-252. http://dx.doi.org/10.1590/ S0101-20611999000200017.

Hansen, C. E., Del Olmo, M., \& Burri, C. (1998). Enzyme activities in cocoa beans during fermentation. Journal of the Science of Food and Agriculture, 77(2), 273-281. http://dx.doi.org/10.1002/(SICI)10970010(199806)77:2<273::AID-JSFA40>3.0.CO;2-M.

Hansen, C. E., Mañez, A., Burri, C., \& Bousbaine, A. (2000). Comparison of enzyme activities involved in flavour precursor formation in unfermented beans of different cocoa genotypes. Journal of the Science of Food and Agriculture, 80, 1193-1198.

Huang, Y., \& Barringer, S. A. (2010). Alkylpyrazines and other volatiles in cocoa liquors at $\mathrm{pH} 5$ to 8 , by Selected Ion Flow Tube-Mass Spectrometry (SIFT-MS). Journal of Food Science, 75(1), C121-C127. PMid:20492142. http://dx.doi.org/10.1111/j.1750-3841.2009.01455.x.

Larcher, G., Bouchara, J. P., Annaix, V., Symoens, F., Chabasse, D., \& Tronchin, G. (1992). Purification and characterization of a fibrinogenolytic serine proteinase from Aspergillus fumigatus culture filtrate. FEBS Letters, 308(1), 65-69. PMid:1644203. http://dx.doi. org/10.1016/0014-5793(92)81052-N.

Lima, E. D. P. A., Pastore, G. M., Barbery, S. D. F., Garcia, N. H. P., Brito E. S., \& Lima, C. A. A. (2001). Obtenção e utilização da enzima 
polifenoloxidase extraída de polpa de pinha (Annonasquamosa l.) madura no melhoramento do sabor do cacau (Theobromacacao L.). Revista Brasileira de Fruticultura, 23(3), 709-713.

Lowry, O. H., Rosebrough, N. J., Farr, A. L., \& Randall, R. J. (1951). Protein measurement with the Folinfenol reagent. The Journal of Biological Chemistry, 193(1), 265-275. PMid:14907713.

Marco, J. L., \& Felix, C. R. (2002). Characterization of a protease produced by a Trichoderma harzianum isolate which controls cocoa plant witches' broom disease. BMC Biochemistry, 34, 33-38. PMid:11835696.

Misnawi, J. S., Nazamid, S., \& Jamilah, B. (2002). Activation of remaining key enzymes in dried under-fermented cocoa beans and its effect on aroma precursor formation. Food Chemistry, 78(4), 407-417. http://dx.doi.org/10.1016/S0308-8146(02)00120-6.

Nascimento, W. C. A., \& Martins, M. L. L. (2006). Produção de proteases por Bacillus sp SMIA-2 crescido em soro de leite e água de maceração de milho e compatibilidade das enzimas com detergentes comerciais. Ciência e Tecnologia de Alimentos, 26(3), 582-588.

Oetterer, M. (2006). Tecnologias de obtenção do cacau, produtos do cacau e do chocolate. In M. Oetterer, A. Regitano d'Arce \& M. H. F. Spoto (Orgs.), Fundamentos de Ciência e Tecnologia de Alimentos (Vol. 1, pp. 1-50). Barueri: Manole.

Silva, F. A. S. E., \& Azevedo, C. A. V. (2006). A new version of the Assistat: statistical assistance software. In Proceedings of the 4th World Congress On Computers In Agriculture (pp. 393-396). Orlando, USA. St. Joseph: American Society of Agricultural Engineers.

Silva, M. R. O., Santiago, A. L. C. M. A., Souza, P. M., Correia, J., SouzaMotta, C., Moreira, K. A., Porto, A. L. F., \& Lima, J. L. Fo. (2003).
Estudo de métodos de extração de protease termostável produzida pelo Penicillium aurantio griseum. In Anais do $14^{\circ}$ Simpósio Nacional de Fermentações, Florianópolis, Brasil.

Sodré, G. A. (2007). A espécie Theobroma cacao: novas perspectivas para a multiplicação de cacaueiro. Revista Brasileira de Fruticultura, 29(2).

Sturm, A. (1999). Invertases primary structures, functions, and roles in plant development and sucrose partitioning. Plant Physiology, 121(1), 1-7. PMid:10482654. http://dx.doi.org/10.1104/pp.121.1.1.

Turk, B. (2006). Targeting proteases: successes, failures and future prospects. Nature Reviews. Drug Discovery, 5(9), 785-799. PMid:16955069. http://dx.doi.org/10.1038/nrd2092.

Yusep, I., Jinap, S., Jamilah, B., \& Nazamid, S. (2002). Influence of carboxypeptidases on free aminoacid, peptide and methylpyrazine contents of under-fermented cocoa beans. Journal of the Science of Food and Agriculture, 82(13), 1584-1592. http://dx.doi.org/10.1002/ jsfa.1232.

Voigt, J., Voigt, G., Heinrichs, H., Wrann, D., \& Biehl, B. (1994). In vitro studies on the proteolytic formation of the characteristic aroma precursors of fermented cocoa seed: the significance of endoprotease specificity. Food Chemistry, 51(1), 7-14. http://dx.doi. org/10.1016/0308-8146(94)90040-X.

Wang, S. L., Chen, Y. H., Wang, C. L., Yen, Y. H., \& Chern, M. K. (2005). Purification and characterization of a serine peptidase extracellularly produced by Aspergillus fumigatus in a shrimp and crab shell powder medium. Enzyme and Microbial Technology, 36(5-6), 660-665. http:// dx.doi.org/10.1016/j.enzmictec.2004.10.006. 